\title{
P01-044 - Uncommon manifestations of familial Mediterranean
}

\author{
A Beglaryan ${ }^{*}$, K Ginosyan $^{2}$, A Ayvazyan ${ }^{2}$ \\ From 7th Congress of International Society of Systemic Auto-Inflammatory Diseases (ISSAID) \\ Lausanne, Switerland. 22-26 May 2013
}

\section{Introduction}

Familial Mediterranean fever (FMF) is the most common autoinflammatory disease characterized by recurrent selflimited attacks of fever accompanying with peritonitis, pleuritis or arthritis. The testing of MEFV gene expanded the frame of various clinical manifestations of FMF.

\section{Objectives}

The aim of this study is to determine systemic uncommon non-classical manifestations of FMF and reveal the possible association with autoimmune diseases.

\section{Methods}

We examined 50 patients (27 male, 23 female) with FMF. The mean age of patients was $34.7 \pm 12.2$. FMF was determined clinically and approved by testing of MEFV gene. To reveal systemic manifestations of FMF investigation of all organ-systems was carried out.

\section{Results}

Classical symptoms of FMF: abdominalgy, thoracalgy, arthralgy with recurrent fever and pleuritis, splenomegaly, hepatomegaly were seen in almost all patients. Monoarthritis was met in $36(72 \%)$ and polyarthritis in $8(16 \%)$ patients. $40(80 \%)$ patients developed spondyloarthrtitis, in 11 cases (22\%) unilateral sacroiliitis and in $29(58 \%)$ bilateral sacroiliitis was observed. All patients with sacroiliitis fulfilled the classification criteria of the European Spondyloarthropathy Study Group for the diagnosis of seronegative spondyloarthropathy. 10(25\%) patients of 40 that having sacroiliitis developed significant limitation of lumbar motion, which was assessed by Schober's test $(1-2 \mathrm{~cm})$, had bilateral sacroiliits grade III-IV and fulfilled the modified New York criteria for ankylosing spondylitis. HLA B-27 was examined in 15 patients with symptoms of spondyloarthropathy. In 7 patients it was negative and in 8-positive. In19 (38\%) from 50 patients coxarthrosis was revealed and 2 patients underwent total endoprothesis of hips. Skin involvement also was observed during the observation: $4(8 \%)$ of them developed erythema similar "butterfly" rash, livedo reticularis and photosensitivity with high titer of circulating immune complexes, ANA and anti-dsDNA antibodies like systemic lupus erythematosus, 1 patient had hemorrhagic rash on legs with developing of hemorrhagic vasculitis. In 1 patient trophic ulcers, miscarriage were developed with high titer of anticardiolopin autoantibodies as in classic antiphospholipid syndrome. Scleroderma-like syndrome was developed in 1 patient with Raynaud's phenomenon and skin induration of wrists and face and pneumofibrosis. Also panniculitis (1 patient), aphthae ( 2 patients), angiorethinopathy(2 patients), mononeyropathy and polyneyropathy ( 2 patients respectively), pneumonitis (4 patients), xerophthalmia (1 patient) like Sjogren's syndrome were observed. The prevalent mutation of MEFV gene was M694V- in 38patients $(79.1 \%)$, from which $8(16.7 \%)$ were homozygote and 14(29\%) were heterozygote $(\mathrm{M} 694 \mathrm{~V} / \mathrm{N})$.

\section{Conclusion}

FMF may have systemic manifestations of autoimmune diseases. It may be due to vascular involvement especially in accompaning amyloidosis cases. The peculiarity of ankylosing spondylitis-like syndrome in FMF is its independent existence from carrying HLA B-27 antigen.

\section{Disclosure of interest}

None declared. 


\section{Authors' details}

'Rheumatology, Center of family planning and sexual health, Yerevan,

Armenia. ${ }^{2}$ Internal Diseases, Yerevan State Medical University, Yerevan,

Armenia.

Published: 8 November 2013

doi:10.1186/1546-0096-11-S1-A47

Cite this article as: Beglaryan et al:: P01-044 - Uncommon

manifestations of familial Mediterranean. Pediatric Rheumatology 201311

(Suppl 1):A47.

Submit your next manuscript to BioMed Central and take full advantage of:

- Convenient online submission

- Thorough peer review

- No space constraints or color figure charges

- Immediate publication on acceptance

- Inclusion in PubMed, CAS, Scopus and Google Scholar

- Research which is freely available for redistribution

Submit your manuscript at 